ing view, derived from both animal and clinical observations, is that their effect basically resembles that of the inert, linear devices but is reinforced or complemented by factors with specific contraceptive properties..$^{356}$ In rats and monkeys copper stimulates a massive endometrial exudation of leucocytes, believed to be embryotoxic, ${ }^{7}$ but this effect seems to be less pronounced and less constant in the human uterus. In addition, it is thought that copper devices may modify the physicochemical properties, and hence penetrability, of the cervical mucus $;^{8}{ }^{9}$ be directly toxic to spermatozoa, possibly by an alteration of the copper-zinc ratio in the head region, affecting sperm motility $;^{10}$ or induce changes in the metabolism and enzyme content of the endometrium which render it, or the uterine environment, unsuitable for implantation. ${ }^{5} 611 \mathrm{~A}$ comprehensive account of the hormonal, histological, and histochemical changes induced by copper devices in women has been published by Hagenfeldt. ${ }^{11}$

The second type of system is based on the local contraceptive action of progesterone released from an intrauterine capsule or other device and affecting the endometrium directly. This approach assumes that excess progestogen may lead to abnormal endometrial development as much as its deficiency and in this way interfere with implantation. Several years ago progestogen-impregnated I.U.D.s were shown to induce a secretory endometrium in monkeys, ${ }^{12}$ and this was confirmed by Scommegna et al..$^{13}$ in women fitted with intrauterine silastic (silicone polymer) capsules containing 10-30 mg progesterone. Subsequent endometrial biopsy showed decidual or pseudodecidual changes in the endometrium and definite atrophy of the uterine glands, unaccompanied, however, by suppression of ovulation or appreciable disturbance of the menstrual pattern. Scommegna et al. chose a silastic capsule since this material permits the slow release of its contents and is therefore capable of prolonged drug delivery.

Since then the same group of workers has conducted an extensive clinical trial ${ }^{14}$ of the method, in which nearly 250 women were fitted with a modified $\mathrm{T}$-shaped device releasing minute amounts of progesterone (on average $128 \mu \mathrm{g} /$ day) from an attached silastic capsule, and tested for six months. No pregnancies occurred during this period when an active, progesterone-releasing I.U.D. was present in the uterine cavity, though one woman conceived in whom the device had become displaced into the cervix. Special investigations in selected subjects indicated that the contraceptive effect of the device was due neither to inhibition of ovulation nor to changes in the cervical mucus but was probably related to decidual transformation and glandular atrophy of the endometrium induced by the constantly released progesterone.

In spite of their preliminary nature, the results of the trial are distinctly promising. It seems that intrauterine progesterone, like intrauterine copper, can efficiently protect against pregnancy; also that progesterone does so by a local, direct and hence "economical" mechanism of action, and one which does not seem to interfere with ovulation and the hormonal control of the cycle.

Much remains to be done to substantiate and extend these observations. In particular, it will be necessary to prove the clinical efficacy and acceptability of the method on a larger scale, monitor the continued retention of the capsule within the uterus, and try to prolong its pharmacological life span, perhaps by substituting progestogens released more slowly than progesterone. Even so, the feasibility of using intrauterine devices or carriers as local delivery systems for specific contraceptive agents appears to be established: the technique deserves further exploration.
1 Zipper, J. A., Medel, M., and Prager, R., American fournal of Obstetrics and Gynecology, 1969, 105, 529.

2 Zipper, J. A., et al., American fournal of Obstetrics and Gynecology, 1969, $105,1274$.

${ }^{3}$ Zipper, J. A., et al., American Fournal of Obstetrics and Gynecology, 1971,

Williams, M., and Snowden, R., The Gravigard Device (Cu-7). Family Planning Research Unit, University of Exeter, Report No. 8, 1974.

5 Chang, C. C., and Tatum, H. J., Contraception, 1970, 1, 265.

Chang, C. C., Tatum, H. J., and Kincl, F. A., Fertility and Sterility, 1970, $21,274$.

7 Cuadros, A., and Hirsch, J. G., Science, 1972, 175, 175.

Elstein, M., and Ferrer, K., Fournal of Reproduction and Fertility, 1973, 32, 109.

${ }^{9}$ Oster, G. K., Fertility and Sterility, 1972, 23, 18.

10 Chandler, J. A., personal communication, 1974

11 Hagenfeldt, K., Acta endocrinologica, Suppl. 169, 1972,

12 Doyle, L. L., and Clewe, T. H., American fournal of Obstetrics and Gynecology, 1968, 101, 564

13 Scommegna, A., et al. Fertility and Sterility, 1970, 21, 201

14 Scommegna, A., et al., Obstetrics and Gynecology, 1974, 43, 769.

\section{N.H.S. Finances}

As the nation begins to tighten its belt to face a fall in living standards in coming months, prudent businessmen and families are examining their budgets and looking for economies. Within the N.H.S., in contrast, all seems to be confusion. The cuts made in 1973 in Government expenditure on health ahve not been restored; the hospital building programme has come to a virtual halt ${ }^{1}$ while as a result of inflation many area health authorities have overspent their budgets to such an extent that they may run out of money completely before the end of the financial year. ${ }^{1}$ Yet the Government seems reluctant to admit there is any crisis, and very little attention was paid to the financial plight of the N.H.S. during the election campaign.

The lack of electoral interest in the N.H.S. reflects the broad agreement on major issues among the political partiesprivate practice and prescription charges have a negligible effect on N.H.S. finances and generate little heat outside the health professions. There seems to be a political consensus that the N.H.S. should continue to be financed from central taxation-and that means that it will need to continue to compete for money with education, defence, and the social services.

While the politiciars make reassuring noises doctors and other health service workers are in no doubt that this source of income will prove far from adequate in the immediate future. Last week the Royal Colleges and Faculties took an unprecedented step by sending a joint statement to the Government asking for a careful scrutiny of the funding of the N.H.S. (the full text is printed at p. 237). The gap between medical care provided for patients and what might be achieved in the light of modern knowledge is widening, says the statement; health service workers are finding that they are not being given the resources to allow them to make use of their training; and the combination of this frustration with low pay has seriously lowered morale.

In these circumstances an open, honest assessment of the financial possibilities is essential. Economies can be planned only when a realistic estimate of income is available. The colleges have no political axe to grind and they should be supported by the profession in their request for plain dealing by the Government. If, as seems inevitable, the N.H.S. is to face some years of financial stringency then resources will need to be rationed; and in helping to decide priorities the informed advice of those working in the Service will be vital.

1 House of Commons Committee on Expenditure, Fourth Report. London, H.M.S.O., 1974. See British Medical Fournal, 1974, 3, 697. 